\title{
THE IMPACT OF PEER RESPONSE ON EFL LEARNERS' WRITING DESCRIPTIVE TEXT
}

\author{
Nur Rohmat \\ English Education Study Program, Faculty of Language Education, IKIP Siliwangi, Indonesia \\ E-mail: nrohmat1994@gmail.com \\ Irma Savitri Sadikin \\ English Education Study Program, Faculty of Language Education, IKIP Siliwangi, Indonesia \\ E-mail: savitrisadikin@gmail.com
}

APA Citation: Rohmat, N., \& Sadikin, I. S. (2018). The impact of peer response on EFL learners' writing descriptive text. Indonesian EFL Journal, 5(1), 59-66. doi: 10.25134/ieflj.v5i1.1611.

Received: 20-09-2018

Accepted: 29-11-2018

Published: 01-01-2019

\begin{abstract}
The aim of this study is to find out whether or not there is a significant difference between students who are taught by using peer response technique and those who are not taught by using peer response technique in writing descriptive text. This study used quantitative research method with quasi-experimental design. The population of this research was the 175 students of tenth grade at SMK Bandung Barat, while the sample was 26 students of X 2 Farmasi and X TLM. Writing test was used as the instrument of the study. The data were collected from the result of pretest and posttest. Then, the gain of both classes was analyzed by using t-test in SPSS. The result of the study showed that the mean of gain score in experimental class was 0.38 and the mean of gain score of students in control class was 0.22 . It meant that there was difference in improvement between both classes. The hypotheses testing showed that sig. 2 tailed values (p) was 0.000 while alpha $\alpha$ was 0.05 . In other words, $\mathrm{p}<\alpha$. It indicated that $\mathrm{H}_{0}$ was rejected. Therefore, it can be concluded that there is a significant difference between students who are taught by using peer response technique and those who are not taught by using peer response technique in writing descriptive text.
\end{abstract}

Keywords: descriptive text; peer response technique; teaching; writing.

\section{INTRODUCTION}

Humans are social beings who need to communicate in order to do their daily activity and interact to each other. In doing communication, humans need a device which is called language. According to Genneti (2014), language can be described as a medium which is used by people to interact to others. Humans use language in a number of purposes, such as giving information, giving command, entertaining, etc.

Nowadays, humans' interaction is more complex. They do not only interact with people who share same language, but also interact with others who have different language. Thus, humans need an international language which can be understood by those who do not share a same language. One of international languages commonly used is English. English plays an important role in all aspects of life in this era, such as communication, science, and technology. It has been used in many countries all over the world as first language, second language, or foreign language. Indonesia is one of countries which include English as subject in its curriculum.

In Indonesia, English is learned as a foreign language. It is because Indonesian people have local languages as their first language and Bahasa Indonesia as their second language. Based on 2013 Curriculum, English is one subject which needs to be taught in junior high school and senior high school. Like any other English learners, Indonesian students have to master 


\section{Nur Rohmat \& Irma Savitri Sadikin}

The impact of peer response on EFL learners' writing descriptive text

four skills of English, which are listening, speaking, reading, and writing. Writing is one skill that shows students' achievement in academic setting. In other words, writing skill has strong influence in a person's academic success (Rizqiya, Pamungkas, \& Inayah, 2017)

Nunan (2003, p. 88) explains that writing is a process which involves physical and mental act to make ideas, express them, and organize them into sentences and paragraphs which will be clear for reader. The purpose of writing is to express writers' ideas, whether it is for themselves or their audiences. By having good writing skill, the writers will be able to share ideas to wide range of audience without through face to face or telephone conversation. Most people use writing to communicate to each other. Writing can help people to express their idea in written form and writing is used for communication.

Nunan's statement also indicates that writing is complicated to be acquired. It is in accordance with Westwood (2008) who stated that writing is difficult to be acquired since it needs effective coordination of many different cognitive, linguistic and psychomotor processes in its development. Writing is a complex process that allows the writer to explore thoughts and ideas and make them visible and concrete (Tiwari, 2005). In order to make the written text clear for audiences, the writers need to do some processes, such as making ideas, expressing ideas, and organizing the ideas into sentences and paragraphs. Brown (2001, p. 335) stated that writing involves some processes including thinking, drafting, and revising that need specialized skills to create a written product. It means that the writers discover thoughts and ideas lying beneath the surface of their mind. Writing is not an easy skill because writers must be able to explore their own idea and thought. Writing needs more practice, as well as revising and editing. The writers need to ensure that the words and phrases used are clearly expressing their intended meaning. In other words, writing is more complicated than other language skills.
In writing, we do not only think about what we will write, but we have to be creative. Mastering more vocabularies and grammar is needed. Besides, obtaining some feedback is helpful for English learners to create a good writing.

Feedback can be obtained not only from the teacher, but also from other learners. Peer response is one technique which allows learners develop their writing skill by obtaining feedback from other learners. According to Nelson and Murphy (1993, cited in Torwong, 2003), peer response is a technique in which students provide comments on other students' writing drafts so that those students can develop their own written work. Hansen and Liu (2005) also formulates that peer response is writing which involves students as the source of information; students have responsibility to provide comments to others' writing. Characteristic of peer response is students collaborate during the writing process to help each other (Topping \& Ehly, 1998 cited in Hoogeveen, 2012). In using peer response, learners are involved as source of information which gives feedback to another's draft. Peer response allows the writer to hear the feedback from others and continue to think about their writing (Spear, 1988). Learners could develop their written draft based on feedback given by other learners (Nelson and Murphy, 1993 cited in Ramadia, Yandri, \& Tanjung, 2014). It can then be concluded that peer response is a technique in writing which allows students to provide comments or feedback to other students' writing in order to develop their writing.

According to Hansen and Liu (2005), peer response could give some benefits when it is implemented properly, such as generating rich source of information, enhancing intercultural communication, and giving the students sense of group cohesion. Moreover, Spear (1988) formulates three advantages of peer response. First, students will be able to take responsibility for their own learning in the classroom. Second, students' participation will be encouraged 
while working in the small group. Third, peer response is an effective way for the teacher to be facilitator in learning process. Last, peer response provides opportunities through-out for novice writers to behave like their more experienced counterparts. In addition, Richards and Renandya ( 2002) stated that students enjoy in sharing writing to each other. Barron (2009) also stated that the role of the students as responders is to improve their ability to revise their own. It means that giving respon to others' writing can improve students' writing ability.

On the other hand, peer-response has some problems as stated by Spear (1988). Some of them are; 1) confused expectation about the groups' purpose and the individual's role in it; 2) inability to read group member's text analytically; 3) misperceptions about the nature of revision and of writing as a process.

However, teacher can solve those problems by facilitating students while using peer-response technique in the classroom. Teacher should give clear explanation about what students should do in the classroom. Besides, the teacher also needs to guide the students in the learning process.

In terms of peer response technique, there are some researchers who have investigated the impact of peer response technique towards students' writing ability; such as Ramadia et al. (2014), Rozuna (2012), Situmeang (2016), and Tang \& Tithecott (1999). The result of their research showed that peer response had positive impact on students' writing development.

The use of peer response technique is also relevant with 2013 Curriculum which demands the teacher to conduct a lesson which encourages students to be more active and creative. Spear (1988) states that peer response technique could encourage students to take responsibility for their own learning in the classroom.

By considering the explanation above, the writers are interested in conducting a research in the domain of peer response and writing, especially writing descriptive text. According to Gerot and Wignell (1995), descriptive text is a type of texts in which its social function is to describe a particular person, place, or thing. Another expert, Anderson and Anderson (1998) proposed that descriptive text describes particular person, place or thing without including personal opinions. In addition, Oshima and Hogue (1997 cited in Anggun, 2016) stated that descriptive writing appeals to the senses, so it tells how something looks, feels, smells, tastes, and/or sounds.

Learning descriptive genre is essential for students, in order they can describe vivid and proper information (Emilia \& Christie, 2013 cited in Anggun, 2016). Since learning descriptive genre is important, students should be able to write descriptive text correctly. Students' descriptive text need to fulfill the structure and language features of the text.

In relation to the structure, Gerot \& Wignell (1995, p. 208) formulated the generic structure of descriptive text, which are identification and description. Identification is part of text which introduces a particular thing. Meanwhile, description is part of text which describes a particular thing.

Furthermore, Gerot and Wignell (1995, p. 208) and Knapp and Watkins (2005, p. 98-100) formulated a number of language features of descriptive text. First, descriptive text focuses on specific participants. The participants can be a character, animal, or any other particular things. Second, present tense is predominantly used. Third, the verbs used in descriptive text are relational verb, action verb, and mental verb. Relational verb is used to describe the appearance and parts/function of the thing described. Then, action verb is used to describe behavior. Meanwhile, mental verb id used to describe feelings. Fourth, adjectives are used to add extra information to nouns and may be technical, every day or literary, depending on the text. Fifth, adverbs are used to add extra information to verbs to provide more detailed description. Sixth, adverbial phrases are used in to add more information about manner, place or time. 


\section{Nur Rohmat \& Irma Savitri Sadikin}

The impact of peer response on EFL learners' writing descriptive text

In this research, the writers would like to investigate whether or not there is significant difference between students who are taught by using peer response technique and those who are not taught by using peer response technique in writing descriptive text. By knowing the difference between two classrooms, it can provide information to to the writers whether peer response technique is effective or not to teach writing.

\section{METHOD}

In this research, the writers used quantitative research method with quasi-experimental design. This research was conducted at SMK Bandung Barat in academic year 2017/2018. The writers selected 175 students of tenth grade as population. Then, the sample of this research was 26 pharmacy students of X-2 as experimental class and 26 students of $\mathrm{X}$ TLM as control class.

In collecting data, the writers administered pretest and postest to figure out the students' ability in writing descriptive text. In both pretest and postest, the students were asked to write descriptive text about tourism place. The students were also given some guided questions to help them to develop their ideas in writing. The writers implemented scoring rubric adapted from Brown (2001) to assess students' descriptive text. The scoring rubric consists of five aspects, namely content, organization, grammar, vocabulary, and mechanic. Each of these aspects has assessment score 1-4. Thus, students can get maximum score of 20 and minimum score of 5 .

In analyzing the data, first, the writers calculated gain score of pretest and postest. Gain score is used to see the differences between posttest score and pretest score, whether it is increased or decreased. Moreover, gain score can be interpreted into three categories; which are High $(\geq 0.70)$, Normal $(0.31-0.69)$, and Low $(\leq 0.30)$. Then, gain score would be statistically analyzed by using parametric test (t-test) in order to know the difference between the improvement of writing ability of students in experimental class and students in control class. Furthermore, there were several steps that should be done before using the t-test, such as computing normality test and homogeneity test.

\section{RESULTS AND DISCUSSION}

The results of the research presented the score of pretest, posttest, and gain of both experimental and control class. The pretest score was obtained before the writers gave the treatment. Based on the result of pretest, the mean score of experiment class was 50.77. The lowest score was 30. It was obtained by one student. The student obtained the minimum score in almost all aspects, whether it is content, organization, vocabulary, and mechanic. In grammar aspect, the student's score was 2 which mean there were numerous grammatical inaccuracies. Then, the highest score is 70 and there were two students who obtained the score. The score was obtained since the students got the score of 3 in almost all of scoring aspects. It could be interpreted that there is a little errors in the students' descriptive text. Moreover, the most frequent score acquired by students was 50 . It was obtained by seven students. Most students who obtained 50 in their final score got score of 2 in each scoring aspect. It meant that there were a lot of mistakes found in their written text.

Meanwhile, the mean score of pretest of control class was 50.19. It was lower than mean score of experiment class. Moreover, the lowest score in control class was 25 . The student got score of 1 in all scoring aspects. It meant that mistakes frequently occurred in the student's written text. Then, the highest score is 75. Those scores were each obtained by one student. The student got score of 3 in all aspects which could be interpreted that students' mistakes in writing are little. The most frequent score appeared was 50. It was obtained by 9 students. The students' scores in all aspects were dominated by number of 2. It can be concluded that the descriptive text of most students had a lot of mistakes.

The posttest was administered in both experiment and control class after the 
treatment. It was administered in order to see whether peer response technique can develop students' writing skill or not, especially in writing descriptive text. In experimental class, the mean score of posttest was 70 . Then, the highest score increased to 85 meaning that it was higher than highest score in pretest. The score was obtained since the student got 4 on content and mechanic aspect. While, on other aspects the student got score of 3. The lowest score was 55. Compared to score of pretest, the lowest score is also increased. However, the student had problem in mechanic aspect, in which the student got only 1 point. The most frequent score appeared was 70. Mostly, students got score 2 in organization aspect. It can be interpreted that students had problem in organization aspect.

On the other hand, the mean score of control class's posttest was 60.58 . Then, the highest score was 85. Compared to score of pretest, the highest score was increased. The lowest score was 3. Even though it was higher than the lowest score of pretest, the student still had problem in some aspects, such as organization, grammar, and mechanic. It can be seen from the score of these aspects in which they were 1 point. The most frequent score appeared was 65 . Most of students had a little problem on organization and mechanic aspects. The most dominant score in organization and mechanic aspects were 2 .

In brief, the mean score of posttest in experimental class was higher than mean score of posttest in control class. Thus, it indicated that the treatment given to students in experimental class affected the students' writing skill. However, it is needed to see the score of gain in order to see the level of score improvement.

In analyzing the data, the writers used analysis of t-test in IBM SPSS Statistic to compare the score of gain in experiment class and control class. The gain scores were analyzed since the objective of this research was to investigate whether or not there was significant difference between students who are taught by using peer response technique and those who are not taught by using peer response technique. In other words, the aim of this research was to compare the improvement of students writing ability between control class and experimental class.

However, before analyzing the data by using t-test, there were some tests that should be completed; they were normality test and homogeneity test. The normality test was analyzed in order to know whether or not the data were distributed normally. The result of normallity test explained that the significance level or probability value (p) of gain score in the experimental class was 0.099 and in the control was 0.200 . Thus, the result of normality test proved that the significance level or the probability value (p) was higher than (>) the degree of significance $(\alpha=0.05)$. It indicated that the data of gain score of experimental and control classes were distributed normally.

Moreover, homogeneity test was taken in order to know the similarity of the sample taken from the population. Based on the criteria of homogeneity hypotheses, if the significance level or probability value is higher than the degree of significance ( $\alpha=$ 0.05 ), then the sample data had homogenous variance. In contrast, if the significance level or probability value is lower than the degree of significance $(\alpha=0.05)$, then the sample data did not have homogenous variance. The result of homogeneity test explained that the significance level or probability value (p) from both experimental and control classes was 0.402 . It means that the significance level or probability value (p) of the data was higher than the degree of significance $(\alpha=$ 0.05 ). Therefore, it could be interpreted that the sample data had homogenous variance.

Based on the calculation of gain score, it showed that the mean of gain score in experimental class was 0.38. It can be interpreted that the level of students' improvement in writing was normal. Mostly, gain scores obtained by students in experimental class were 0.50 which means it was normal. Then, the highest gain score 
was 0.60 . It was less than 0.70 . Therefore, its level of improvement was normal. Unfortunately, the lowest gain score was 0 which obtained by one student. It means that the student ability was not improved.

On the other hand, in control class, the mean of students' gain score was 0.22 . It meant that improvement level of students in control class was low. The highest gain score was 0.67 . Its level was normal since it was less than 0.70 . Then, most students obtained 0.10 which means its level was low. The lowest gain score was 0 point.

Further, parametric test was conducted to see whether or not there was significant difference between improvement of students' writing skill in experiment class and improvement of students' writing skill in control class. The writers used the value of $5 \%$ or 0.05 as the significance value $(\alpha)$ of the study. The hypothesis stated:

1. If sig. 2 tailed (p) value $>$ alpha $(\alpha=$ 0.05 ), then $\mathrm{H}_{0}$ was accepted. In other words, there was no significant difference between students who are taught by using peer response technique and those who are not taught by using per response technique.

2. If sig. 2 tailed (p) value $<$ alpha $(\alpha=$ 0.05 ), then $\mathrm{H}_{0}$ was rejected. In other words, there was significant difference between students who are taught by using peer response technique and those who are not taught by using per response technique.

Table 1. The Result of $t$-test

\begin{tabular}{ll}
\hline \multicolumn{2}{c}{ Paired Sample Test } \\
\hline Mean & $-1,20346$ \\
Std.deviation & .44751 \\
Std. Error Mean & .06206 \\
95\% confidence & $-1,32805$ (lower) \\
interval of the & $-1,07887$ (upper) \\
difference & $-19,393$ \\
$\mathbf{t}$ & 51 \\
df & .000 \\
Sig (2-tailed) & \\
\hline
\end{tabular}

Based on the calculation of parametric test, the value of sig. 2 tailed was 0.000 , in which it was smaller than $\alpha(0.000<0.05)$. It indicated that $\mathrm{H}_{0}$ was rejected. It means that there was significant difference between students who are taught by using peer response technique and those who are not taught by using per response technique.

From the research findings above, it indicated that the students in experimental class obtained better scores in both pretest and posttest rather than in control class. It could be seen from the result of mean scores of both classes. The mean score of pretest in experimental class was 50.77, while in control class was 50.19. Although the mean of pretest score in experiment class was higher than experimental class, the difference between those scores was only 0.58 point. Moreover, the mean score of posttest in experimental class was 70.00 while the mean score of post-test in control class was 60.58 . The difference between them was 9.42 points, in which it was higher than difference of pretest scores.

However, those score had not indicated that students in experimental class had better improvement than students in control class. Therefore, it is needed to see the result of calculation of gain score. The calculation of gain score showed that the mean of experimental class 0.38 , while the mean of control class is 0.22. Based on the interpretation of gain score, the level of improvement in experimental class was normal since it was less than 0.70 and higher than 0.30 . On the other hand, the level of improvement in control class was low. It was because the gain score was less than 0.30 . The result of gain score showed that experimental class had better improvement than control class.

Moreover, in analyzing t-test, if $p<\alpha$, it means that $\mathrm{H}_{0}$ was rejected. Meanwhile, if $\mathrm{p}>\alpha$, it means that $\mathrm{H}_{0}$ was accepted. The result showed that $p$ value was 0.000 and $\alpha$ was 0.05 . It meant that the significance level or probability value (p) was higher than the degree of significance $(\alpha)$. Thus, it indicated that $\mathrm{H}_{0}$ was rejected. In other words, there was a significant difference between students who are taught by using peer response technique and those who are not taught by using peer response technique. It 
also indicated that writing skill of students in experimental class was more improved than students in control class. In other words, peer responsive technique had positive impact in developing students' writing skill, especially in descriptive text.

The result of this study was relevant with the previous studies conducted by Ramadia et al. (2014), Rozuna (2012), Situmeang (2016), and Tang and Tithecott (1999), in which the result of their study showed that peer-response was effective to improve students' writing skill. Furthermore, the writers got some advantages while using peer response technique in teaching writing. First, students were more encouraged to work since peer response involved some small groups. Second, the students had opportunity to learn writing to students who more experienced. Third, students had more time to practice by themselves since the role of teacher was only as facilitator. These advantages were in line with advantages of peer response formulated by Spear (1988), such as: 1) students will be able to take responsibility for their own learning in the classroom, 2) students' participation will be encouraged while working in the small group, 3) peer response is an effective way for the teacher to be facilitator in learning process, and 4) peer response provides opportunities through-out for novice writers to behave like their more experienced counterparts.

In addition, the students could enjoy the process of writing since the teacher less involved in the process of sharing writing. Therefore, students were able to share their ideas freely. This students' behavior is also in accordance with Richards and Renandya (2002) who stated that by using peer response, students enjoy in sharing writing to each other.

However, the writers could not deny that there were problems in using peer response technique to teach writing decriptive text at tenth grade students of SMK Bandung Barat. The problem came when students were in peer response section. They got a little confusion on giving feedback to another's writing. To solve this problem, the writers facilitated and guided them during peer response section. Besides, the writers also tried to give clear explanation about what students should do.

To sum up, peer response technique could be an alternative technique to teach writing descriptive text. The technique gave opportunity to students to work together and give feedback to each other. Furthermore, it gave opportunity to those who had low ability in writing skill to learn from others who were more experienced.

\section{CONCLUSION}

Based on explanation of the data above, it can be concluded that there is a significant difference between students' who are taught by using peer response and those who are not taught by using peer response technique. Students who are taught by using peer response technique had better improvement than those who are not.

The conclusion above is supported by the data of gain score which showed the level of improvement of students in experimental class and control class. The gain score of experimental class was 0.38 , which indicates that the level of improvement is normal. Meanwhile, the gain score of control class was 0.22 . It can be interpreted that the level of improvement is low.

Based on the hypotheses testing, it showed that sig. 2 tailed values (p) was smaller than $\alpha(\mathrm{p}<\alpha) ;(0.000<0.05)$. It indicated that $\mathrm{H}_{0}$ was rejected. Therefore, it proves that there is a significant difference between students who are taught by using peer response and those who are not taught by using peer response technique.

\section{ACKNOWLEDGEMENT}

This article is the result of hard work, support and guidance of several prople. Thus, we would like to express our gratitude to our supervisor, parents, and friends who have given their supports, prayers, guidance, assistance to us in writing this article. 


\section{Nur Rohmat \& Irma Savitri Sadikin}

The impact of peer response on EFL learners' writing descriptive text

\section{REFERENCES}

Anderson, M., \& Anderson, K. (1998). Text types in English 3. Australia: Macmillan Education Australia Pty Ltd.

Anggun, S. K. (2016). An analysis of descriptive text in english textbook using transitivity system (A case study of reading passages). Journal of English and Education, 4(1), 147-158.

Barron, R. (2009). What I wish I had known about peer response groups but didn't. The English Journal, 80(5), 34.

Brown, H. D. (2001). Teaching by principles: An interactive approach to language pedagogy. San Fransisco: Longman.

Genneti, C. (2014). How languages work: An introduction to language and linguistics. New York: Cambridge University Press.

Gerot, L., \& Wignell, P. (1995). Making Sense of functional grammar. Australia: Gerd Stabler.

Hansen, J. G., \& Liu, J. (2005). Guiding principles for effective peer response. ELT Journal, 59(1), 31-38. doi: 10.1093/elt/cci004.

Hoogeveen, M. (2012). Writing with peer response using genre knowledge; classroom intervention study. University of Twente. doi: 10.3990/1.9789036534895.

Knapp, P., \& Watkins, M. (2005). Genre, text, grammar: Technologies for teaching and assessing writing. Sidney: University of New South Wales Press Ltd.

Nunan, D. (2003). Practical English language teaching. Singapore: McGraw-Hill.

Ramadia, G., Yandri, \& Tanjung, F. (2014). Teaching writing paragraphs using e-peer response technique (through blog) at university. Abstract of Undergraduate, Faculty of Education, Bung Hatta University, 3(6), 162-165.
Richards, J. C., \& Renandya, W. A. (2002). Methodology in language teaching. New York: Cambridge University Press.

Rizqiya, R. S., Pamungkas, M. Y., \& Inayah, R. (2017). The use of P.O.W.E.R. learning as a learning strategy to improve students writing competency. OKARA: Jurnal Bahasa Dan Sastra, 11(2), 253-262.

Rozuna. (2012). The effect of using peer response groups technique toward writing ability in narrative text at the second year students of islamic senior high school of Darel Hikmah Pekanbaru. State Islamic University of Sultan Syarif Kasim Riau.

Situmeang. (2016). The effect of peer response technique on students' achievement in writing descriptive text. Universitas Negeri Medan.

Spear, K. (1988). Sharing writing. Porstmouth: Boynton/Cook Publishers.

Tang, G. M., \& Tithecott, J. (1999). Peer response in ESL writing. TESL Canada Journal, 16(2), 2038.

Tiwari, D. (2005). Encyclopedia of modern methods of teaching 7. New Delhi: Cressent.

Torwong, P. (2003). Peer response technique: A proposed model for EFL writing. Suranaree University of Technology.

Westwood, P. (2008). What teachers need to know about reading and writing difficulties. Australia: ACER Press. 